\title{
Coastal Change in Tropical Overseas and Temperate Metropolitan France Inferred from a National Monitoring Network: A Summary from the Current Special Issue
}

\author{
Bruno Castelle $^{\dagger *}$ and Eric Chaumillon ${ }^{\dagger \dagger}$ \\ †UMR 5805 EPOC, CNRS \\ University of Bordeaux \\ Pessac, France \\ †UUMR 7266 LIENSs, CNRS \\ University of La Rochelle \\ La Rochelle, France
}

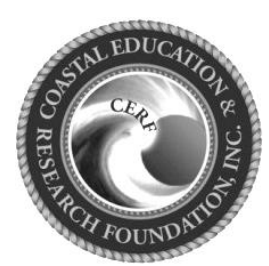

www.cerf-jcr.org

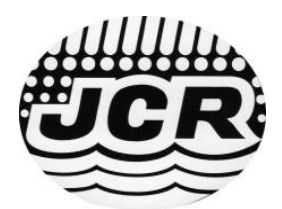

www.JCRonline.org

\begin{abstract}
Castelle, B. and Chaumillon, E., 2019. Coastal change in tropical overseas and temperate metropolitan France inferred from a national monitoring network: A summary from the current special issue. In: Castelle, B. and Chaumillon, E. (eds.), Coastal Evolution under Climate Change along the Tropical Overseas and Temperate Metropolitan France. Journal of Coastal Research, Special Issue No. 88, pp. 3-9. Coconut Creek (Florida), ISSN 0749-0208.
\end{abstract}

This paper provides an overview of the papers published in this Special Issue «Coastal Evolution under Climate Change along the Tropical Overseas and Temperate Metropolitan France » of Journal of Coastal Research. This special issue reflects the large diversity of mainland and tropical French coast and highlights the complex, siteand timescale-specific, combination of factors driving coastal evolution. Many contributions reveal a strong climate control on storm wave activity and, in turn, coastal response. In some contributions, the inherited geology and anthropogenic factors clearly appear affect coastal change. This special issue emphasises the need to monitor the coast combining different means to improve our understanding and predicting capacities of the natural variability of coastal response in a changing climate.

ADDITIONAL INDEX WORDS: Coastal evolution, sandy coast, rocky coast, drivers, monitoring.

\section{INTRODUCTION}

Coastal evolution is governed by myriad nonlinear processes interacting through complex feedbacks covering a wide range of spatial and temporal scales. The respective contribution of the different driving factors of coastal evolution depends on, but not only, the timescales of interest of the type of coast addressed. For instance, while wave- and tide-driven currents are a major driver of sediment transport and, in turn, morphological changes on sandy beaches, geological structure, freeze/thaw cycles and chemical alteration can be critical to cliff retreat. On much longer timescales (decades, centuries and even longer), coastal evolution can be the result of other factors such as changes in sediment supply, coastal vertical motions and sea level rise. In addition, a large range of types and degrees of anthropogenic interventions affect coastal evolution, resulting in a considerable variability of coastal behaviours.

Globally, $24 \%$ of sandy coasts are eroding at a rate exceeding $0.5 \mathrm{~m} /$ year (Luijendijk et al., 2018). All rocky coasts are more or less eroding, with median erosion rates of $2.9,10$ and $23 \mathrm{~cm} /$ year for hard, medium and weak rocks, respectively (Premaillon et al., 2018). During the period 1984-2015, the overall surface of eroded coastal land globally was approximately $28,000 \mathrm{~km}^{2}$, which is approximately twice the surface of gained land (Mentaschi et al., 2018). Climate change will affect the primary drivers of coastal change, driving for instance sea level rise (Cazenave et al., 2014)

DOI: 10.2112/SI88-002.1 received 1 September 2019; accepted in revision 30 September 2019.

*Corresponding author: Bruno.castelle@u-bordeaux.fr

${ }^{\circ}$ Coastal Education and Research Foundation, Inc. 2019 and increased storminess in some regions of the world (Zappa et al., 2013). Globally, increased sea-level-rise will result in increased frequency and intensity of coastal flooding along lowlying coasts (e.g., Vousdoukas et al., 2018). The response of sandy coasts is more complex. There may be a perceivable global shift towards generalized sandy coast erosion only by the middle of the $21^{\text {st }}$ century (Le Cozannet et al., 2016), although this remains quite uncertain (Le Cozannet et al., 2019). While such trends are acknowledged globally, the influence of Climate Change on flooding and particularly erosion hazards locally is virtually unknown as essentially complex and site specific.

In this framework, improving our understanding and predicting capacities of the natural variability of coastal response is of paramount importance, particularly at local scales. This requires (1) a better understanding of the underlying processes; (2) addressing the impact of extreme events; (3) characterizing longterm change including how the impact of extreme events cascade up through the scales and (4) addressing the (cumulative) impacts of local anthropogenic pressures. To meet these objectives, developing and/or improving coastal monitoring networks at sites representative of the natural variability of coastal settings is required. It can in turn provide new insight into coastal change and to improve and validate state-of-the-art coastal evolution models. In France, coastal observation is structured around the federative research infrastructure named ILICO labelled by CNRS-INSU (Cocquempot et al., 2019). ILICO comprises eight network systems amongst which the Service National d'Observation (SNO) DYNALIT collects relevant, long-term, and accurate data on the physical evolution of the coast in metropolitan and oversea France. 


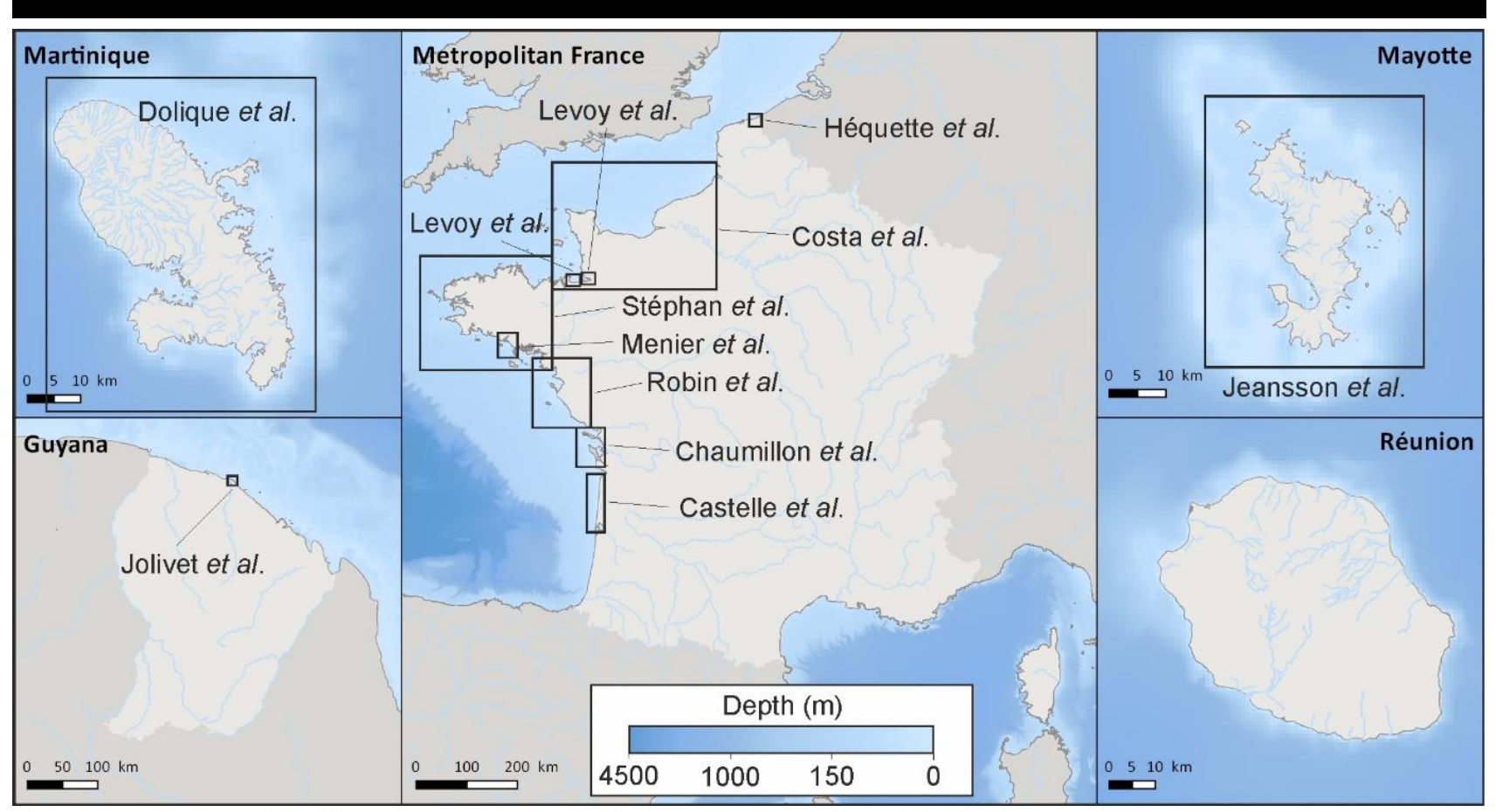

Figure 1. Location map of the different study areas addressed in the framework of this Special Issue

DYNALIT also provides a forum for coastal monitoring discussion including more than 120 researchers from 20 laboratories and 22 universities with 35 coastal monitoring sites.

Encompassing mainland and the five tropical overseas departments, France hosts over $6500 \mathrm{~km}$ of coastline with a large diversity, from micro- to mega-tidal, from sheltered low-energy regions to high-energy storm-dominated coasts, from rocky to depositional coasts, from temperate to tropical climate. France's coasts are located in various geodynamic setting, including passive continental margins, active margins and volcanic islands. French coastal environments include estuaries, deltas, tidal inlets, tidal bays, open sandy coasts, rocky coasts, mixed sedimentaryand-rocky coasts, perched beaches, atolls, with also sites largely affected by biotic processes (e.g., mangrove salt marshes), etc. Therefore, French coasts are representative of a large diversity of global coasts. The present Special Issue of Journal of Coastal Research builds on measurements collected by members of SNO DYNALIT in metropolitan and tropical overseas France, combining local and regional data (Figure 1). This special issue reflects the large diversity of French coast with 10 papers focused on mainland and 3 papers focused on tropical areas. The overall objective of this Special Issue is to provide an overview of the spatial and temporal patterns of coastal evolution and of the primary drivers, which are summarized in the present paper.

\section{SUMMARY OF CONTRIBUTIONS}

Dodet et al. (2019) use measurements and numerical hindcasts to describe waves, tides, storm surges along the $5853 \mathrm{~km}$ of metropolitan France coastlines facing the North Sea, the English Channel, the Atlantic Ocean and the Mediterranean Sea. Despite tropical overseas is overlooked, a large range of wave and tide climates are observed, from low- to high-energy wave climates, and from micro- to mega-tidal ranges. Winter wave climate at the coast, which is critical to flooding and erosion hazards, is strongly correlated with large-scale climate patterns of atmospheric variability, namely the North Atlantic Oscillations (NAO, Hurrell, 1995), particularly for the Mediterranean Sea and the English Channel, and the West Europe Pressure Anomaly (WEPA, Castelle et al., 2017b), particularly for the entire Bay of Biscay. The analysis of long-term sea level trends reveals significant variabilities, with an accelerated sea level rise on average from $1.2 \mathrm{~mm} /$ year over the $20^{\text {th }}$ century to $2.4 \mathrm{~mm} /$ year over the two last decades, ranging locally from $1.23 \mathrm{~mm} /$ year (Roscoff) to $4.25 \mathrm{~mm} /$ year (Nice), with moderate land subsidence ( $<1 \mathrm{~mm} /$ year) for the majority of the France mainland stations.

One of the papers focuses on coastal cliff evolution (Costa $e t$ $a l ., 2019)$. Coastal cliff erosion is typically discontinuous, with sporadic and localized occurrence of mass movement (Figure 2a) which spatial and temporal patterns depend on a complex combination of marine forcing, continental forcing and cliff settings (e.g., lithology, weathering, folding, bedding). Costa $e t$ al. (2019) use a diachronic analysis of the Normandy cliffs showing mean erosion rate of approximately -0.1 to $-0.5 \mathrm{~m} / \mathrm{year}$ in line with other erosion measurements in the English Channel. The large spatial variations of the cliff retreat rates, at the Normandy scale, can be explained by geological structure, especially at the cliff foot, but also by the influence of cliff collapses or anthropogenic obstacles that disrupt the longshore drift. 


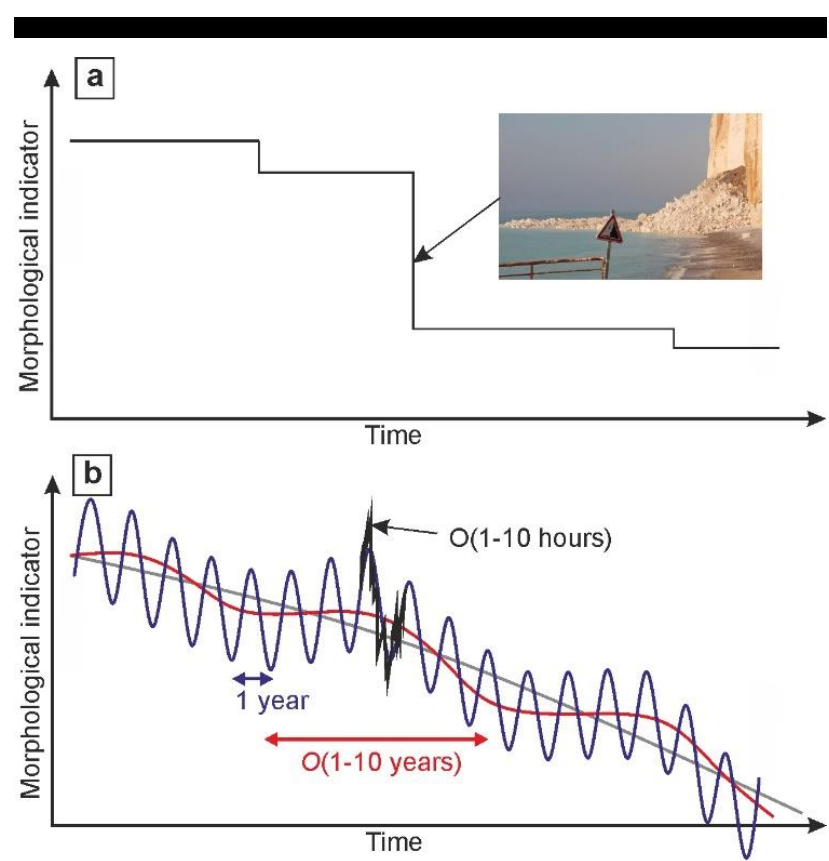

Figure 2. Typical time series of morphological indicator (e.g., shoreline position, volume) for (a) rocky coasts ( $\mathrm{Ph}$. Sandra Beaufils) and (b) sandy coasts.

In contrast with morphological changes of coastal cliffs, the morphological evolution of sedimentary coasts covers a wide range of time and spatial scales, with long-term trends, large interannual and seasonal variability and rapid changes at the scale of severe storm or storm cluster (Figure $2 b$ ). The papers published in this Special Issue show a large range of coastal behaviours and forcing which are synthesised in Figure 3. Open sandy coast can be dominated by accretion in some coastal areas which are moderately exposed to waves (Robin et al., 2019), contrastingly, an acceleration of the shoreline retreat is observed along other coasts (Dolique et al., 2019). The impact of storms on shoreline evolution is highlighted in contrasted coastal environments. Storm-driven shoreline erosion is often highly non-uniform alongshore, from the scale of a few hundreds to thousands of meters enforced by the geometry of the offshore surfzone sandbar(s) (Castelle et al., 2019) or inner shelf sand ridges or sand banks (Héquette et al., 2019). Large regional variability in coastal behaviour and response to storms is found in Brittany due to different exposure to storm wave conditions (Stéphan et al., 2019). Impact of storms is found along the coast of CharenteMaritime, in south-west France, where maximum erosion rates are associated with stormclusters (Chaumillon et al., 2019). Shelly beach ridges, emplaced in estuarine environment, are also controlled by periods of enhanced storminess (Tessier et al., 2019). Contrastingly, for the last 10 years, the hurricane season is not the period with strongest beach erosion along the shoreline of Martinique Island (Dolique et al., 2019). In both tide- and wavedominated environments, the importance of extreme water level, controlled by both tides (lunar and 18.6-yr nodal tidal cycles) and storm surges, is highlighted (Héquette et al., 2019; Stéphan et al., 2019; Tessier et al., 2019). In addition to the tidal control on tidal flat, tidal channels and beach ridges dynamic evolutions, the influence of waves, storms, wind speed and velocity and river discharge is also evidenced (Levoy et al., 2019; Tessier et al., 2019). Some contributions reveal a strong climate control on storm wave activity and, in turn, coastal response (Castelle et al., 2019; Héquette et al., 2019, Tessier et al., 2019). This suggests that it is now critical to link storm wave climate and resulting coastal hazards with large-scale climate patterns of atmospheric variability. The inter-annual variability of the main climate patterns is found to dictate interannual variability of shoreline position.

Interestingly, some studies presented in this issue focus on the behaviour of mixed rocky-and-sedimentary coasts, an intermediate category of shorelines between rocky and sedimentary coast. Along those complex and indented shorelines, the first-order parameters explaining most of the spatial variations in the shoreline evolutions are the presence or absence of bedrock outcrops in the foreshore and/or shoreface (Chaumillon et al., 2019; Menier et al., 2019). The control by antecedent geology highlights two main parameters: the coastal orientation and the basement topography. The coastal orientation controls the wave exposition and consequently the shoreline dynamic (Stephan et al., 2019). The basement topography has controlled the shoreward sediment migration and distribution during the last transgression, itself influencing the dynamic of the present-day coastal sedimentary prism (Menier et al., 2019). The basement topography in the shoreface or lower foreshore is important to shore protection owing to wave dissipation offshore through depth-induced breaking and controls the wave energy on the beach and the shoreline evolution (Chaumillon et al., 2019). This basement topography can be represented by offshore reefs like in Mayotte where their characteristics are found to affect stability and erosion of mangrove along the coast. This results in large regional variability with mangrove system subject to advance or stability in the north and east of Mayotte but exhibiting a clearly regressive pattern along the southern and western shores (Jeansson et al., 2019). Finally, the basement topography also controls the presence or absence and the dynamic of tidal inlets, themselves controlling the evolutions of adjacent shorelines. Beyond the control by external (allocyclic) forcing parameters, internal (autocyclic parameters) are also important drivers of shoreline evolutions and could explain why greatest changes in shoreline evolutions are found close to tidal inlets or close to sandpit terminations dynamic (Chaumillon et al., 2019; Robin et al., 2019; Stephan et al., 2019).

It is important to note that, in a number of contributions of this Special Issue, anthropogenic factors clearly emerge as an important driver of coastal change (Costa et al., 2019; Jeansson et al., 2019; Tessier et al., 2019). Unforeseen side effects of human activities, for example the implementation of dams, sand mining, irrigation systems are other anthropogenic factors that were not addressed. Indeed, their effects is often difficult to discriminate from other factors and need the application of complex numerical models are often required for that purpose. 


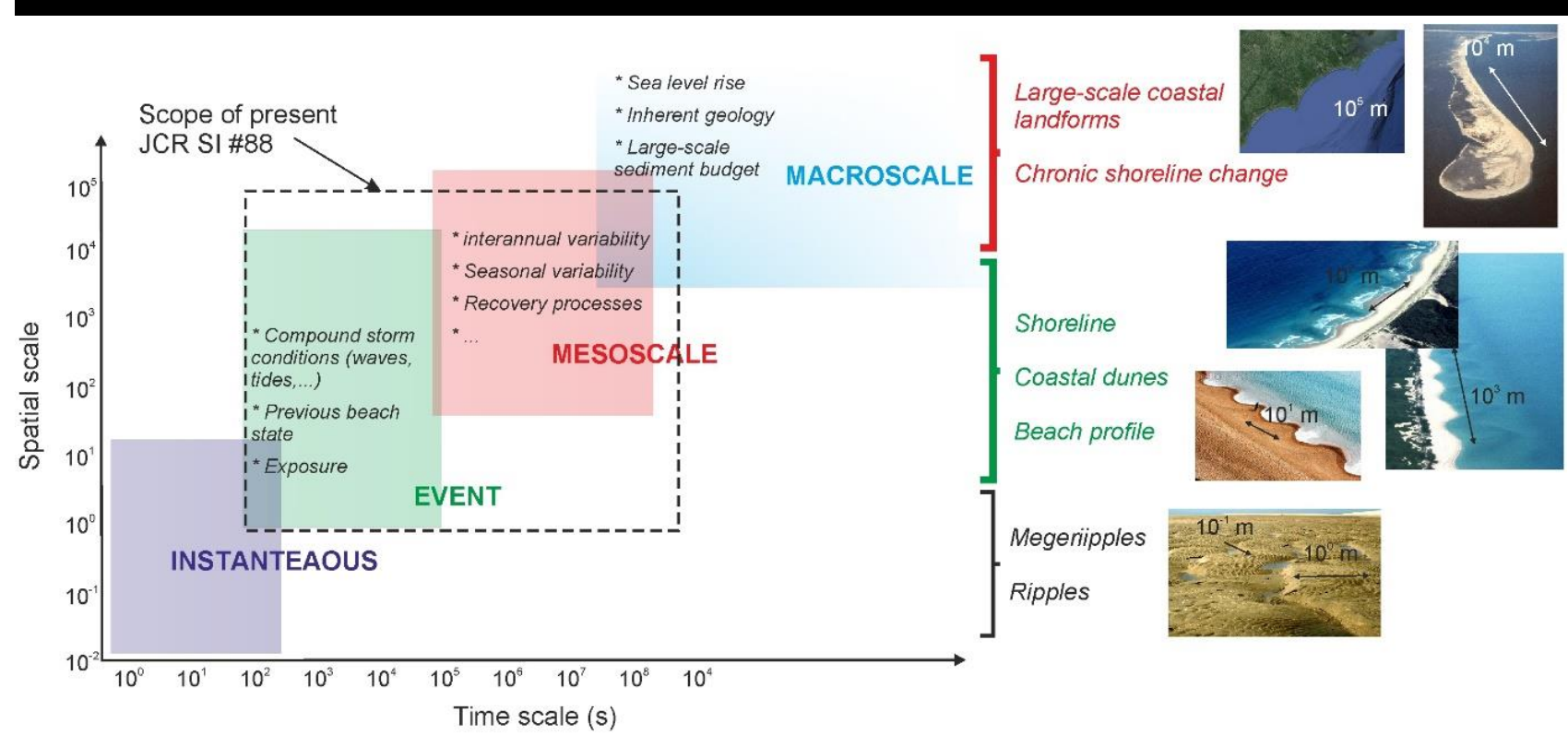

Figure 3. Time and spatial scales associated to coastal morphological changes sandy and gravel coasts, with indication of the spatio-temporal spectra addressed in the present Special Issue.

\section{RECOMMENDATIONS}

Over the last decade, there has been substantial development of coastal evolution monitoring programs worldwide. Some of these monitoring program can now provide coastal evolution time series exceeding 20 years (Turner et al., 2016). As a result, over the last decades there has been an increasing number of journal papers building on well-established monitoring programs collecting, for instance, topographic data (e.g., Castelle et al., 2017a; Harley et al., 2015; Masselink et al., 2014; Yates et al., 2009; Wiggins et al., 2019) and/or video-sensed data (e.g., Pianca et al., 2015; Splinter et al., 2018). Recent studies also now combine different international sites, including some DYNALIT sites (Dodet et al., 2019; Masselink et al., 2016). All these contributions paved large knowledge gaps on the impacts of storms, wave exposure and inherent geology, and large-scale climate patterns of climate and atmospheric variability on coastal response (e.g., Barnard et al., 2017; Dodet et al., 2019). These monitoring data can also be used, for instance, to improve/validate a new generation of hybrid shoreline change models (e.g., Antonilez et al., 2019; Robinet et al., 2018; Vistousek et al., 2018) and satellite-sensed methods inferring shoreline data (Vos et al., 2019). The latter can, in turn, provide insight into global shoreline change (Luijendjik et al., 2018; Mentaschi et al., 2018). Although critical, maintaining such monitoring program is expensive and requires long-term involvement of research teams. Thanks to CNRS-INSU, SNO DYNALIT provides such long-term funding opportunity for a wide range of coastal environments at national scale. Such collective initiative should be encouraged in other countries.

Topographic and video monitoring data are not the only useful source of data. Historic charts and aerial photographs, satellite images, or sediment cores are some of the means that can be combined to provide extensive insight into coastal change at regional scale from the timescales of storms to decades. A good example of this Special Issue is given by Stéphan et al. (2019) for French Brittany. In recent years, photogrammetry using Unmanned Aerial Vehicles (UAVs) has been increasingly used to remotely sense topographic data along for a wide range of coastal environments (e.g., Jaud et al., 2016; Laporte-Fauret et al., 2019; Long et al., 2016). Costa et al. (2019) shows that such approach is critical to survey coastal cliff evolution at high-resolution. It is anticipated that UAVs will also be increasingly used for other monitoring applications, building on video-sensed techniques developed over the last decades for land-based video station for e.g. shoreline/sandbar positions and surface currents (Chickadel et al., 2003; Holman and Stanley, 2007). Collecting bathymetric data also appears critical to our understanding of coastal evolution, but bathymetric surveys in coastal shallow waters require a large investment of time and effort for both data acquisition and processing (Billy et al., 2012). Depth-inversion techniques using permanent land-based video station (Holman et al., 2013) or marine drones must be further developed and appear as a relevant avenue to collect such data.

This Special Issue \#88 of Journal of Coastal Research entitled "Coastal Evolution under Climate Change along the Tropical Overseas and Temperate Metropolitan France" gathers 12 coastal monitoring papers in metropolitan and tropical overseas France from the perspectives of different scientific disciplines (e.g., physical geography, sedimentology, physics). Although these papers do not cover the Mediterranean coastline, nor estuaries, they together provide a decent overview of coastal evolution and primary forcing parameters for a large range of coastal environments. This special issue emphasises the need to monitor the coast combining different means. More efforts should be put 
in exploiting historical data in order to further extend the data backwards and in modern and promising techniques, like UAVs, marine drone and remotely-sensed satellite products to increase both the spatial scales and knowledge of offshore controls and of morphological changes and exchanges between the subtidal and subaerial domains.

\section{ACKNOWLEDGMENTS}

We acknowledge the valuable participation of colleagues and students to this Special Issue. This collective effort was funded by SNO DYNALIT (www.dynalit.fr) labelled by CNRS-INSU.

\section{LITERATURE CITED}

Antolínez, J.A.A.; Méndez, F.J.; Anderson, D.; Ruggiero, P., and Kaminsky, G.M., 2019. Predicting climate driven coastlines with a simple and efficient multi-scale model. Journal of Geophysical Research - Earth Surface, 124, doi:10.1029/2018JF004790.

Barnard, P.L.; Hoover, D.; Hubbard, D.M.; Snyder, A.; Ludka, B.C.; Allan, J.; Kaminsky, G.M.; Ruggiero, P.; Gallien, T.W.; Gabel, L.; McCandless, D.; Weiner, H.M.; Cohn, N.; Anderson, D.L., and Serafin, K.A., 2017. Extreme oceanographic forcing and coastal response due to the 20152016 El Niño. Nature Communications, 8, 14365.

Billy, J.; Chaumillon, E.; Féniès, H., and Poirier, C., 2012. Tidal and fluvial controls on the morphological evolution of a lobate estuarine tidal bar: the Plassac Tidal Bar in the Gironde Estuary (France). Geomorphology, 169-170, 8697.

Castelle, B.; Bujan, S.; Ferreira, S., and Dodet, G., 2017a. Foredune morphological changes and beach recovery from the extreme 2013/2014 winter at a high-energy sandy coast. Marine Geology, 385, 41-55.

Castelle, B.; Dodet, G.; Masselink, G., and Scott, T., 2017b. A new climate index controlling winter wave activity along the Atlantic coast of Europe: the West Europe Pressure Anomaly. Geophysical Research Letters, 44, 1384-1392, doi:10.1002/2016GL072379.

Castelle, B.; Marieu, V., and Bujan S., 2019. Alongshore-variable beach and dune changes on the timescales from days (storms) to decades along the rip-dominated beaches of the Gironde Coast, SW France. In: Castelle, B. and Chaumillon, E. (eds.), Coastal Evolution under Climate Change along the Tropical Overseas and Temperate Metropolitan France. Journal of Coastal Research, Special Issue No. 88, 157-171.

Cazenave, A.; Dieng, H.-B.; Meyssignac, B.; von Schuckmann, K.; Decharme, B. and Berthier, E., 2014. The rate of sealevel rise. Nature Climate Change, 4, 358-361, doi:10.1038/nclimate2159.

Chaumillon, E.; Cange, V.; Gaudefroy, J., Mercle, T.; Bertin, X., and Pignon, C., 2019. Controls on shoreline changes at pluriannual to secular timescale in mixed-energy rocky and sedimentary estuarine systems. In: Castelle, B. and Chaumillon, E. (eds.), Coastal Evolution under Climate Change along the Tropical Overseas and Temperate Metropolitan France. Journal of Coastal Research, Special Issue No. 88, 135-156.
Chickadel, C.C.; Holman, R.A., and Freilich, M.H., 2003. An optical technique for the measurement of longshore currents. Journal of Geophysical Research - Oceans, 108 (11), 28-1.

Cocquempot, L.; Delacourt, C.; Paillet, J.; Riou, P.; Aucan, J.; Castelle, B.; Charria, G.; Claudet, J.; Conan, P.; Coppola, L.; Hocdé, R.; Planes, S.; Raimbault, P.; Savoye, N.; Testut, L., and Vuillemin, R. (2019). Coastal ocean and nearshore observation: A French case study. Frontiers Marine Sciences, 6(324), doi: 10.3389/fmars.2019.00324.

Costa, S.; Maquaire, O.; Letortu, P.; Thirard, G.; Compain, V.; Roulland, T.; Medjkane, M.; Davidson, R.; Graff, K.; Lissak, C.; Delacourt, C.; Duguet, T.; Fauchard, C., and Antoine, R., 2019. Sedimentary Coastal cliffs of Normandy: modalities and quantification of retreat. In: Castelle, B. and Chaumillon, E. (eds.), Coastal Evolution under Climate Change along the Tropical Overseas and Temperate Metropolitan France. Journal of Coastal Research, Special Issue No. 88, 46-60.

Dodet, G., Bertin, X., Bouchette, F., Gravelle, M., Testut, and Wöppelmann, G., 2019. Characterization of sea-level variations along the metropolitan coasts of France: waves, tides, storm surges and long-term changes. In: Castelle, B. and Chaumillon, E. (eds.), Coastal Evolution under Climate Change along the Tropical Overseas and Temperate Metropolitan France. Journal of Coastal Research, Special Issue No. 88, 10-24.

Dodet, G.; Castelle, B.; Masselink, G.; Scott, T.; Davidson, M.; Floc'h, F.; Jackson, D., and Suanez, S., 2019. Beach recovery from extreme storm activity during the 2013-14 winter along the Atlantic coast of Europe. Earth Surface Processes and Landforms, 44, 393-401, doi: 10.1002/esp.4500

Dolique, F.; Sedrati, M.; Charpentier, J.; Jeanson, M.; Cohen, M.; Dupuy, L., and Alami, S., 2019. Beaches seasonal and paroxysmal morphosedimentary dynamics: results of 10 years Martinique coastal observation network. A synthesis. In: Castelle, B. and Chaumillon, E. (eds.), Coastal Evolution under Climate Change along the Tropical Overseas and Temperate Metropolitan France. Journal of Coastal Research, Special Issue No. 88, 172-184.

Harley, M.D.; Turner, I.J., and Short, A.D., 2015. New insights into embayed beach rotation: The importance of wave exposure and cross-shore processes. Journal of Geophysical Research: Earth Surface, 120, 1470-1484, doi:10.1002/2014JF003390.

Héquette, A.; Ruz, M.H.; Zemmour, A.; Marin, D.; Cartier, A., and Sipka, V., 2019. Alongshore Variability in Coastal Dune Erosion and Post-Storm Recovery, Northern Coast of France. In: Castelle, B. and Chaumillon, E. (eds.), Coastal Evolution under Climate Change along the Tropical Overseas and Temperate Metropolitan France. Journal of Coastal Research, Special Issue No. 88, 25-45.

Holman, R.A. and Stanley, J., 2007. The history and technical capability of Argus. Coastal Engineering, 54, 477-491.

Holman, R.A.; Plant, N., and Holland, T., 2013. CBathy: A robust algorithm for estimating nearshore bathymetry. Journal of Geophysical Research - Oceans, 118 (5), 2595-2609. 
Hurrell, J.W., 1995. Decadal Trends in the North Atlantic Oscillation: Regional Temperatures and Precipitation. Science, 269, 676-679.

Jaud, M.; Grasso, F.; Le Dantec, N.; Verney, R.; Delacourt, C.; Ammann, J.; Deloffre, J., and Grandjean, P., 2016. Potential of UAVs for monitoring mudflat morphodynamics (Application to the Seine Estuary, France). ISPRS International Journal of Geo-Information, 5, 50.

Jeansson, M.; Dolique, F.; Anthony, E.J., and Aubry, A., 2019. Decadal-scale dynamics and morphological evolution of mangroves and beaches in a reef-lagoon complex, Mayotte Island. In: Castelle, B. and Chaumillon, E. (eds.), Coastal Evolution under Climate Change along the Tropical Overseas and Temperate Metropolitan France. Journal of Coastal Research, Special Issue No. 88, 195-208.

Jolivet, M.; Gardel, A., and Anthony, E.J., 2019. Multi-decadal Changes on the Mud-dominated Coast of Western French Guiana: Implications for Mesoscale Shoreline Mobility, River-mouth Deflection, and Sediment Sorting. In: Castelle, B. and Chaumillon, E. (eds.), Coastal Evolution under Climate Change along the Tropical Overseas and Temperate Metropolitan France. Journal of Coastal Research, Special Issue No. 88, 185-194.

Laporte-Fauret, Q.; Marieu, V.; Castelle, B.; Michalet, R.; Bujan, S., and Rosebery, D., 2019. Low-cost UAV for highresolution and large-scale coastal dune change monitoring using photogrammetry. Journal of Marine Science and Engineering, 7(3), 63, doi:10.3390/jmse7030063.

Le Cozannet, G.; Bulteau, T.; Castelle, B.; Ranasinghe, R.; Woppelmann, G.; Rohmer, J.; Bernon, N.; Idier, D.; Louisor, J., and Salas-y-Mélia, D., 2019. Quantify Uncertainties of Sandy Shoreline Change Projections as Sea Level Rises. Scientific Reports, 9, 42, doi:10.1038/s41598-018-37017-4.

Le Cozannet, G.; Oliveros, C.; Castelle, B.; Garcin, M.; Idier, D.; Pedreros, R., and Rohmer, J., 2016. Uncertainties in sandy shorelines evolution under the Bruun rule assumption. Frontiers Marine Sciences, 3, doi:0.3389/fmars.2016.00049.

Levoy, F., Anthony, E.J., Dronkers, J., Monfort, O. and Montreuil, A.-L., 2019. Short-term to decadal-scale sand flat morphodynamics and sediment balance of a megatidal bay: Insight from multiple LiDAR datasets. In: Castelle, B. and Chaumillon, E. (eds.), Coastal Evolution under Climate Change along the Tropical Overseas and Temperate Metropolitan France. Journal of Coastal Research, Special Issue No. 88, pp. 61-76.

Long, N.; Millescamps, B.; Guillot, B.; Pouget, F., and Bertin, X., 2016. Monitoring the topography of a dynamic tidal inlet using UAV imagery. Remote Sensing, 8, 387.

Luijendijk, A.; Hagenaars, G.; Ranasinghe, R.; Baart, F.; Donchyts, G., and Aarninkhof, S., 2018. The state of the world's beaches. Scientific Reports, 8(1), doi:10.1038/s41598-018-24630-6.

Masselink, G.; Austin, M.; Scott, T.; Poate, T., and Russell, P., 2014. Role of wave forcing, storms and NAO in outer bar dynamics on a high-energy, macro-tidal beach. Geomorphology, 226, 76-93.

Masselink, G.; Castelle, B.; Scott, T.; Dodet, G.; Suanez, S.; Jackson, D., and Floc'h, F., 2016. Extreme wave activity during 2013/2014 winter and morphological impacts along the Atlantic coast of Europe. Geophysical Research Letters, 43, 2135-2143, doi: 10.1002/2015GL067492.

Menier, D.; Mathew, M.; Cherfils J.-B.; Ramkumar, M.; Estournès, G.; Koch, M.; Guillocheau F.; Sedrati, M.; Goubert, E.; Gensac, E.; Le-Gall, R., and Novico, F., 2019. Holocene sediment mobilization in the inner continental shelf of the Bay of Biscay: Implications for regional sediment budget offshore to onshore. In: Castelle, B. and Chaumillon, E. (eds.), Coastal Evolution under Climate Change along the Tropical Overseas and Temperate Metropolitan France. Journal of Coastal Research, Special Issue No. 88, 110-121.

Mentaschi, L.; Vousdoukas, M.I.; Pekel, J.-P.; Voukouvalas, E., and Feyen, L., 2018. Gloabal long-term observations of coastal erosion and accretion. Scientific Report, 8, 12876, doi:10.1038/s41598-018-30904-w.

Pianca, C.; Holman, R.A., and Siegle, E., 2015. Shoreline variability from daysto decades: Results of long-term videoimaging. Journal of Geophysical Research, 120, 21592178, doi:10.1002/2014JC010329.

Prémaillon, M.; Regard, V.; Dewez, T.J.B., and Auda, Y., 2018. GlobR2C2 (Global Recession Rates of Coastal Cliffs): a global relational database to investigate coastal rocky cliff erosion rate variations. Earth Surface Dynamics, 6, 651-668, doi:10.5194/esurf-6-651-2018, 2018.

Robin M.; Juigner M.; Luquet F., and Audère M., 2019. Assessing surface changes between shorelines from 1950 to 2011: The case of a 169-km sandy coast, Pays de la Loire (W France). In: Castelle, B. and Chaumillon, E. (eds.), Coastal Evolution under Climate Change along the Tropical Overseas and Temperate Metropolitan France. Journal of Coastal Research, Special Issue No. 88, 122-134.

Robinet, A.; Idier, D.; Castelle, B., and Marieu, V., 2018. A reduced-complexity shoreline change model combining longshore and cross-shore processes: the LX-Shore model. Environmental Modelling \& Software, 109, 1-16.

Splinter, K.D.; Gonzalez, M.V.G.; Oltman-Shay, J.; Rutten, J., and Holman, R.A., 2018. Observations and modelling of shoreline and multiple sandbar behaviour on a high-energy meso-tidal beach. Continental Shelf Research, 159, 33-45.

Stéphan, P.; Blaise, E.; Suanez, S.; Fichaut, B.; Autret, R.; Floc'h, F.; Cuq, V.; Le Dantec, N.; Ammann, J.; David, L.; Jaud, M., and Delacourt, C., 2019. Long, Medium, and Short-Term Shoreline Dynamics of the Brittany Coast (Western France). In: Castelle, B. and Chaumillon, E. (eds.), Coastal Evolution under Climate Change along the Tropical Overseas and Temperate Metropolitan France. Journal of Coastal Research, Special Issue No. 88, 89-109.

Tessier, B.; Poirier, C.; Weill, P.; Dezileau, L.; Rieux, A.; Mouazé, D.; Fournier, J., and Bonnot-Courtois, C., 2019. Evolution of a shelly beach ridge system over the last decades in a hypertidal open-coast embayment (western Mont-Saint-Michel Bay, NW France). In: Castelle, B. and Chaumillon, E. (eds.), Coastal Evolution under Climate Change along the Tropical Overseas and Temperate Metropolitan France. Journal of Coastal Research, Special Issue No. 88, 77-88.

Turner, I.L.; Harley, M.D.; Short, A.D.; Simmons, J.A.; Bracs, M.A.; Phillips, M.S., and Splinter, K.D., 2016. A multi- 
decade dataset of monthly beach profile surveys and inshore wave forcing at Narrabeen, Australia. Scientific Data, 3(160024), doi:10.1038/sdata.2016.24.

Vitousek, S.; Barnard, P.L.; Limber, P.; Erikson, L., and Cole, B., 2017. A model integrating longshore and cross-shore processes for predicting long-term shoreline response to climate change. Journal of Geophysical Research, 122 (4), 782-806, doi:10.1002/2016JF004065.

Vos, K.; Harley, M.D. ; Splinter, K.D. ; Simmons, J.A., and Turner, I.L., 2019. Sub-annual to multi-decadal shoreline variability from publicly available satellite imagery. Coastal Engineering, 150, 160-174.

Vousdoukas, M.I.; Mentaschi, L.; Voukouvalas, E.; Verlaan, M.;
Jevrejeva, S.; Jackson, L.P., and Feyen, L., 2018. Global probabilistic projections of extreme sea levels show intensification of coastal flood hazard. Nature Communications, 9, 2360, doi:10.1038/s41467-018-04692w.

Wiggins, M.; Scott, T.; Masselink, G.; Russell, P., and McCarroll, R.J., 2019. Coastal embayment rotation: Response to extreme events and climate control, using full embayment surveys. Geomorphology, 327, 385-403.

Yates, M.L.; Guza, R.T., and O'Reilly, W.C., 2009. Equilibrium shoreline response: observations and modeling. Journal of Geophysical Research, 114(C09014), doi: 10.1029/2009JC005359. 